\title{
Diversity and distribution of diapausing aquatic invertebrates in inland wetlands: An ecosystem conservation viewpoint
}

\author{
Joaquín Muñoz*
}

Department of Wetland Ecology, Estación Biológica de Doñana (CSIC), Pabellón del Perú, Av. María Luisa, s/n. 41013, Seville, Spain

\author{
KEYWORDS \\ Wetlands; \\ Continental \\ zooplankton; \\ Invasive species; \\ Ecosystem \\ management
}

\begin{abstract}
Summary
Inland wetlands are worldwide distributed and have been heavily impacted in recent decades by human activities such as commerce, recreation, and food sources. The direct consequences of these activities on aquatic systems are changes in hydrology and salinity alterations, and the introduction of exotic species. Recent large-scale ecological and genetic studies across several countries and continents indicate that population structure, regional endemism, and geographic speciation patterns are common in passively dispersed aquatic invertebrates contradicting previous predictions of homogeneous genetic distribution. This essay discusses the main processes that shape these patterns and determine the biodiversity and geographic distribution of diapausing aquatic invertebrates in inland wetlands. Large-scale geographical studies to describe general patterns and to understand genetic and ecological processes determining the biogeography of cosmopolitan species are needed. Further knowledge of these issues should provide invaluable information allowing development of appropriate conservation management policies for inland waters across entire ecosystems, landscapes, and geographic regions.
\end{abstract}

\section{Introduction}

Globalisation (i.e. inter-continental trade) is probably the main factor acting on the current global geographic distribution of many species

\footnotetext{
*Tel.: +349542323 40; fax: +34954621125.

E-mail address: quini@ebd.csic.es.
}

(Smith et al. 2007). It has facilitated the transport of species from their original habitats to new zones, increasing the chance of invasion events around the world with significant ecological and conservation negative impacts (Amat et al. 2007; Georgiev et al. 2007; Gisbert \& López 2007; Green et al. 2005; Hufbauer 2008; Phillips \& Shine 2006; Vilá \& Gimeno 2006). 
Global and large-scale studies are currently being considered as a need to: understand global distribution patterns; underlie adaptive population divergence; assess geographic speciation; and uncover 'cryptic' lineages in several species (Mabuchi et al. 2008; Mills et al. 2007; Muñoz et al. 2008a; Naiman 2008; Picó \& van Groenendael 2007). From a conservation point of view, the species and the genetically isolated lineages identification, as well as knowing the processes that generate and maintain biodiversity and determine the geographic distribution of species (native and invasive) are essential issues, and large-scale approaches are necessary.

Inland wetlands represent a good example of the scenario described above. These ecosystems can be found all around the world and are characterised by a patchy distribution (i.e. water bodies isolated from each other), but with important biotic connectivity between them (Amezaga et al. 2002). Because wetlands support both terrestrial and aquatic biota and are unusually diverse, they are the focus of large-scale conservation programs (Convention on wetland 1971; De Roeck et al. 2007; Mitsch \& Gosselink 2000). Nevertheless, these ecosystems are hardly pressured by the presence of invasive species and globally threatened by hydrological and salinity alterations (Balian et al. 2008; Díaz et al. 1998; Dudgeon et al. 2006; Velasco et al. 2006).

Unlike other invertebrate and vertebrate organisms, many passively dispersed aquatic invertebrates, inhabiting worldwide patchy wetlands, show high dispersal capacity (i.e. high potential gene flow) contrasting with a pronounced population genetic differentiation (see De Meester et al. 2002). In the case of inland zooplankter (nonmarine) a geographic homogenisation of genotypes was presumed because of passive dispersal of their diapausing eggs via waterfowl (Figuerola \& Green 2002; Green et al. 2008). Due to the high dispersal rate and colonisation capacity, a lack of geographic speciation was also assumed for these kind of organisms (Mills et al. 2007). However, recent phylogenetic and phylogeographic analyses have uncovered an unexpectedly high degree of population genetic differentiation and 'cryptic' lineages in a wide range of passively dispersed continental zooplanktonic species, which includes anostracans, cladocerans, copepods, and rotifers amongst others (De Gelas \& De Meester 2005; Hebert 1998; Hebert et al. 2003b; Ishida \& Taylor 2007; Ketmaier et al. 2005, 2003; Muñoz et al. 2008a; Paland et al. 2005; Penton et al. 2004; but see Bohonak \& Jenkins 2003 for a review). Additionally, recent studies suggest that geographic speciation, which was supposedly inexistent in small invertebrate organisms, is an evolutionary process well identified in globally distributed aquatic invertebrates (Mills et al. 2007). This means that much more emphasis must be focused on large-scale studies when dealing with these worldwide taxa. The consequences of these findings in continental wetlands should lead to a new point of view of conservation biology strategies (e.g. ecosystem-based-management; see Grumbine 1994).

This article highlights some processes that determine the biodiversity and geographic distribution of diapausing aquatic invertebrates in inland wetlands: range expansion; regional endemism and genetic structure; invasive species; and geographic speciation. Finally, as pointed out by different authors (Clucas et al. 2008; Muñoz 2007; Picó \& van Groenendael 2007), some conservation implications from a regional and ecosystem-basedmanagement point of view are also discussed, which could be of interest to conservation biologists and managers.

\section{Regional endemism, genetic structure and range expansion in diapausing aquatic invertebrates}

Many aquatic invertebrates inhabiting continental patchy wetlands produce diapausing stages during their life cycle (i.e. encysted embryos called cysts or resting eggs). Resting eggs can be found in the wetland sediment constituting egg banks (Hairston 1996), which allow the persistence of populations at extreme conditions (Cáceres 1997; Van Stappen 2008). But another primary process in which cysts are involved is the passive dispersal via waterfowl (see Green \& Figuerola 2005 for reviews). These specific characteristics could lead to believe in a homogeneous population genetic distribution, with high gene flow rate, which should lead to panmixia (Mayr 1963), and subsequently to the absence of genetic structure among distant wetlands. However, recent surveys have found regional genetic endemism (i.e. local highly differentiated genetic lineages) and high genetic structure in a few species. For instance, Gómez et al. (2000) reported in rotifers regional endemism at short-medium geographic scales as an effect of glacial refugia in the Iberian Peninsula. Muñoz et al. (2008a) showed in an anostracan the same level of regional endemism, but also at a large-scale (Mediterranean Basin and South Africa). To explain this 'paradox' (e.g. high dispersal and colonisation capacity versus high genetic structure), the monopolization hypothesis (De Meester et al. 2002) 
proposes that a persistent founder effect leads to high $F_{S T}$ values among neighbour populations. Founder effect together with the high growth rate could allow resident genotypes in a wetland impede the establishment of the immigrant ones, or keep immigrant genotypes at very low, almost undetectable, frequencies.

In contrast, few studies carried out in obligate parthenogenetic aquatic invertebrates indicate that some lineages have a 'clonal behaviour' (i.e. identical genotype that can be shared among highly distant wetlands) (Mergeay et al. 2005; Weider et al. 1999a, 1999b). The presence of parthenogenetic lineages in a large geographic range has been attributed, among other processes, to their high capacity to colonise new available sites after the last glaciation (see Haag \& Ebert 2004). On the other hand, examples of geographic parthenogenesis (i.e. the geographically distinct distribution of asexual and related sexual organisms - Vandel 1928) and differentiated range expansion have been reported in a few species showing how postglacial recolonisation shapes genetic structure of asexual lineages (Schön 2007; Zierold et al. 2007).

However, not only biological and ecological processes must be taken into account. The role of anthropogenic activities is one of the main factors affecting the current distribution of species. For instance, the same clone has been retrieved more than $5000 \mathrm{~km}$ apart in an American Daphnia pulex clone (Mergeay et al. 2005), but this is attributed to human unintentional introduction by humans and not to natural dispersal. In the genus Artemia, recent surveys about a parthenogenetic lineage, with a global distribution except America, indicate that the origin of parthenogenesis could have been in Central Asia followed by a rapid range expansion to the rest of Mediterranean countries (Muñoz et al., unpublished results). But it is unclear how this parthenogen lineage arrived to Australia or other continents, hypotheses include the role of human or bird spreading this organism (McMaster et al. 2007).

The ecological (e.g. colonisation of new available sites and posterior spread) and evolutionary processes (e.g. adaptation to local environment) shaping the among-wetlands genetic differentiation in diapausing aquatic invertebrates are not understood to date, mainly due to the absence of information on certain criteria (e.g. large-scale surveys, role of anthropogenic activities, large unexplored regions around the world, genomic assessments to investigate local and regional adaptation). Hence, multidisciplinary approaches and new genetic tools (e.g. genomics) are expected to provide invaluable information to understand the basis of theses processes aimed to guide a rational planning of anthropogenic activities, which have important conservation implications beyond the knowledge of geographic and genetic distribution of these kind of organisms.

\section{Diapausing invasive species in inland wetlands}

Gherardi (2007) stated 'The value of inland waters to humankind is obviously infinite and the induced changes in the goods and services they provide have a strong impact on human welfare'. Although wetland ecosystems were thought to be not overly vulnerable to biological invasions (Sakai et al. 2001), recent studies show that they are equally or more invaded than other types of ecosystems (Gherardi 2007). Certainly, humans are the principal beneficiaries of wetland services, but paradoxically they are the main cause of their diversity and dynamic changes. For instance, the role of human as dispersal vector for crustacean zooplankton has increased the natural dispersal rate up to 50,000-fold (Hebert \& Cristescu 2002), including several invasive species used in economic activities such as aquaculture.

In general, successful invasion events are characterised by two related phenomena, the lack of enemies, parasite's or diseases (Williamson \& Fitter 1996), and/or the introduction of unknown pathogens into native areas (Walker et al. 2008). Although direct evidence showing a relationship between the parasite's role and invasive success is purely anecdotal to date, few studies on wetland invertebrate species have described the prevalence and abundance of parasites in native species being higher than in invasive ones (Georgiev et al. 2007 and therein references). For instance, Artemia franciscana (Branchiopoda, Anostraca), a welldocumented invasive species in Europe and other continents (Amat et al. 2007; Ruebhart et al. 2008), is used as food in aquaculture businesses all around the world displacing the natural native Artemia populations. However, the $A$. franciscana impact is not only affecting the native species, but it is also transforming the dynamic and food web of hypersaline wetland ecosystems due to its elusive capacity and detection by waterfowl and influence on the life cycle of bird parasites (see Georgiev et al. 2007 and references therein for more details).

Although several invasive crustaceans with resistant propagules (i.e. diapausing eggs) have been reported to modify the wetland dynamic (Frisch et al. 2006; Panov et al. 2004), possibly the most 
dramatic case study is the invasive species A. franciscana. This species spread through 3000 hectares in only three years after a single humanmediated inoculation in Brazil, and was found at 55 ponds later (Mura et al. 2006). The aggressive invasive behaviour of this species has been highlighted in the Mediterranean Basin where A. franciscana has dominated natural hypersaline wetlands and replaced native Artemia species in a few years, affecting directly the habitat dynamic (see Georgiev et al. 2007). This invasive anostracan fits almost all the biological attributes required to be an 'ideal' invader, such as high genetic diversity and phenotypic plasticity, large native geographic range, association to human activities and high dispersal rate (Amat et al. 2005; Ruebhart et al. 2008 and references therein). In addition, the conjunction among human-mediated dispersal (Amat et al. 2007) and posterior natural dispersal via waterfowl (Green et al. 2005) increase the potential invasive of this crustacean in nonindigenous regions (Muñoz 2007).

Several actions could be suggested in the management of inland wetland ecosystems to control the invasive events of aquatic invertebrates (e.g. control of importation and releasing, use of native resistant propagules in aquaculture, installation of aquaculture businesses at large distances from natural wetlands, maintenance of resistant propagule collections of native species). However, this author believes that further genetic and ecological studies are necessary to compile more information and a better understanding on the effective dispersal versus potential dispersal, and adaptation to local environments from both native and invasive species. All these studies would contribute to better management policies on conservation biology of wetland ecosystems.

\section{Geographic speciation in diapausing aquatic invertebrates}

As in marine organisms, where one might expect a different mode of speciation to the typical geographic speciation of land organisms (Dawson \& Hammer 2008), recent phylogenetic and phylogeographic evidence indicates a gap in our knowledge on geographic speciation events in zooplankter and microscopic organisms in general as an main process that generate biodiversity, suggesting a review of our understanding of global biodiversity (Mills et al. 2007). Several recent studies reveal potential geographic speciation events in inland diapausing aquatic invertebrates. For instance, Zierold et al. (2007) found a deep genetic structure and population division in the crustacean Triops cancriformis showing evidence to propose a new African species in the genus Triops. Mills et al. (2007) reported a high genetic differentiation in Brachionus plicatilis sensu strictus despite its global distribution, suggesting possible geographic speciation events in this potentially 'panmictic' group of aquatic invertebrates. In Artemia, phylogenetic and phylogeographic surveys at a global geographic scale show the presence of several undetermined species proposed for a taxonomic re-evaluation (Hou et al. 2006; Muñoz et al. 2008a; Tizol-Correa 2006).

Regarding speciation events and the wishes to discover the global biodiversity of species, the present identification of species through molecular tools (i.e. 'DNA barcode' - Hebert et al. 2003a) has come to assist the traditional morphological methods. It has allowed the discovery of new 'cryptic' lineages and potential species in several kinds of organisms. Its use for delineating closely related species in understudied groups has received several criticisms because of the need of identification based on solid taxonomic foundations (Meyer \& Paulay 2005; see Strugnell \& Lindgren 2007 for a review). Nevertheless, the major importance of this approach falls on the capacity for detecting new genetic lineages to date un-described. Although Hebert et al. (2003a) established that the $\mathrm{COI}$ mitochondrial gene is a very good 'global bio-identification system' for animals, it has been tested in only a few crustacean studies (Costa et al. 2007; deWaard et al. 2006; Muñoz et al. 2008a). While genetic studies have revealed a few candidate cryptic species in highly studied vertebrate groups (Hebert et al. 2004a), the potential for detecting new species is much greater in invertebrates (e.g. Gómez et al. 2002; Hebert et al. $2004 \mathrm{~b})$. In many cases, the kinds of variation that separate invertebrate species, such as ecological traits, physiological tolerance, and chemical mating, are not easily accessible to human observations (Knowlton et al. 1993). The different ways of accessing relevant traits in order to identify taxonomic groups have resulted in differences between the proportion of theoretical biodiversity (expected) and that which is currently described (observed). For example, ratios of expected versus observed diversity range from around two-fold for branchiopod crustaceans (Adamowicz \& Purvis 2005) to nine-fold in a group of rotifers (Gómez et al. 2002). In addition, new investigations which try to identify new species or speciation events in zooplankter, combining genetic, morphological, and ecological information, are necessary to reveal new insights not previously recognised within 
investigations based on morphology alone (Hebert et al. 2004b; Ortells et al. 2003).

\section{Conservation implications}

Any human exploited organism often confronts their economical interests and those to protect the environment and local genetic resources (Gajardo \& Beardmore 2001). For instance, humans have used Artemia for centuries to provide several advantages for salt production in hypersaline wetlands (Dhont \& Sorgeloos 2002, chap. IV). More recently it has been subject of study to improve operative methods to optimise resting eggs (cysts) production used in aquaculture (e.g. abandoned hypersaline wetlands to produce salt) (Baert et al. 1997). This species is currently an important invader of natural hypersaline ecosystems in several non-native countries, such as Australia, China, Iran, Japan, Kenya, Madagascar, Mediterranean Basin countries, New Zealand and Vietnam (Muñoz et al. 2008b; Ruebhart et al. 2008).

Traditionally, biodiversity studies as well as biodiversity conservation measures have been focused on those species with social, political, or economic interests (e.g. charismatic flagship species), without paying attention to invertebrates that can be crucial to maintaining the natural dynamic of ecosystems. Fortunately, this tendency has changed in the last decade, focusing on entire ecosystem and landscape management (Clucas et al. 2008; Muñoz 2007; Picó \& van Groenendael 2007). Specifically, wetlands are considered in conservation programmes such as the Ramsar Convention (Ramsar Convention Bureau 2005) mainly because they support endangered species or the presence of big plant communities and high vertebrates, such as waterfowl (Boix et al. 2008; Frisch et al. 2006). Nevertheless, evidence presented shows that inland wetland ecosystems exhibit important ecological and evolutionary traits 'into the water' (i.e. aquatic invertebrates). The conservation implications of the existence of regional endemism, invasive species with human-mediated dispersal, and undetected geographic speciation over large areas around the world in a large amount of aquatic invertebrate taxa, make us believe that each independent unit (i.e. wetlands or regions with a group of wetlands genetically connected) should be considered from an ecosystem/landscape conservation point of view. This author believes that identifying the geographical structure of the genetic variation (i.e. regional endemism and cryptic lineages at short and large-scale) and understanding the dispersal processes of diapausing zooplankter (native and invasive) should become a conservation priority if we want to avoid greater disturbances on biodiversity and dynamics of wetland ecosystems.

To achieve this goal, two lines of approaches could be adopted: control and knowledge. Firstly, we need to control the importation and/or release of exotic species by means of local, national and/or international agreements, as other authors have pointed out (Green et al. 2005; Ruebhart et al. 2008). Secondly, we need to understand how the exotic species become invasive species, and how they affect native species/lineages (e.g. genetic diversity and species diversity) and the dynamics of wetlands as a whole (Muñoz et al. 2008b). The first goal would involve mainly managers and governments, which should recognise in their policies the aquatic conservation at ecosystem or regional level rather than compartmentalising their conservation efforts on specific and isolated wetlands. For the second one, the genotyping of populations with neutral molecular markers (e.g. microsatellites) and the use of recent advances in techniques, such as analyses with genome-wide approaches and high-throughput techniques, would allow us to determine over a large geographic scale the genetically independent wetland groups to be considered in conservation measures. At the same time, it would allow us to determine how the invasive species are spreading and replacing native identified species or lineages. These processes should provide us the tools to design effective conservation strategies to protect the vulnerable and 'easily penetrable' wetlands. And more importantly, we will have the potential to understand the ecological and evolutionary processes involved in biological invasions of passively dispersal aquatic invertebrates.

In summary, this essay wants to stress not only the importance to determine the global diversity and geographic distribution of zooplanktonic species, but also the need to understand the processes that generate and maintain biodiversity and those that determinate the biogeography of both native and invasive species. Knowing these processes will give us the possibility to develop suitable conservation management policies (some of them outlined here as the key points of such policy) for entire ecosystems, landscapes, and geographic regions.

\section{Acknowledgements}

I am indebted to F. Xavier Picó for his constructive comments and suggestions on all steps of this 
manuscript, from earlier drafts to final version. This essay was partially funded by the Spanish Ministerio de Educación y Ciencia (projects CGL 2005-02306 and CGL 2006-05085).

\section{References}

Adamowicz, S. J., \& Purvis, A. (2005). How many branchiopod crustacean species are there? Quantifying the components of underestimation. Global Ecology and Biogeography, 14, 455-468.

Amat, F., Hontoria, F., Navarro, J. C., Vieira, N., \& Mura, G. (2007). Biodiversity loss in the genus Artemia in the Western Mediterranean Region. Limnetica, 26, 177-194.

Amat, F., Hontoria, F., Ruiz, O., Green, A. J., Sánchez, M. I., Figuerola, J., et al. (2005). The American brine shrimp as an exotic invasive species in the western Mediterranean. Biological Invasions, 7, 37-47.

Amezaga, J. M., Santamaría, L., \& Green, A. J. (2002). Biotic wetland connectivity-Supporting a new approach for wetland policy. Acta Oecologica, 23, 213-222.

Baert, P., Anh, N. T. N., Quynh, V. D., \& Hoa, N. V. (1997). Increasing cysts yields in Artemia culture ponds in Vietnam: The multi-cycle system. Aquaculture Research, 28, 809-814.

Balian, E. V., Segers, H., Lévêque, C., \& Martens, K. (2008). An introduccion of the Freshwater Animal Diversity Assesment (FADA) project. Hydrobiologia, 595, 3-8.

Bohonak, A. J., \& Jenkins, G. (2003). Ecological and evolutionary significance of dispersal by freshwater invertebrates. Ecology Letters, 6, 783-796.

Boix, D., Gascón, S., Badosa, A., Brucet, S., LópezFlores, R., Martinoy, M., et al. (2008). Patterns of composition and species richness of crustaceans and aquatic insects along environmental gradients in Mediterranean water bodies. Hydrobiologia, 597, 53-69.

Cáceres, C. E. (1997). Temporal variation, dormancy, and coexistence: a field test of the storage effect. Proceeding of the National Academy of Sciences, USA, 94(17), 9171-9175.

Clucas, B., McHugh, K., \& Caro, T. (2008). Flagship species on covers of US conservation and nature magazines. Biodiversity and Conservation, 17, 1517-1528.

Convention on wetlands. (1971). Ramsar Convention on Wetlands of International Importance. Ramsar, Iran. Available in web site 〈http://www.ramsar.org/ >.

Costa, F. O., deWaard, J. R., Boutillier, J., Ratnasingham, S., Dooh, R. T., Hajibabaei, M., et al. (2007). Biological identificacion through DNA barcodes: The case of Crustacea. Canadian Journal of Fisheries and Aquatic Sciences, 64, 272-295.

Dawson, M. N., \& Hammer, W. M. (2008). A biophysical perspective on dispersal and the geography of evolu- tion in marine and terrestrial systems. Journal of the Royal Society Interface, 5, 135-150.

De Gelas, K., \& De Meester, L. (2005). Phylogeography of Daphnia magna in Europe. Molecular Ecology, 14, 753-764.

De Meester, L., Gómez, A., Okamura, B., \& Schwenk, L. (2002). The Monopolization Hypothesis and the dispersal-gene flow paradox in aquatic organisms. Acta Oecologica, 23, 121-135.

De Roeck, E. R., Vanschoenwinkel, B. J., Day, J. A., Xu, Y., Raitt, L., \& Brendonck, L. (2007). Conservation status of large branchiopods in the western cape, South Africa. Wetlands, 27(1), 162-173.

deWaard, J. R., Sacherova, V., Cristescu, M. E. A., Remigio, E. A., Crease, T. J., \& Hebert, P. D. N. (2006). Probing the relationships of the branchiopod crustaceans. Molecular Phylogenetics and Evolution, 39, 491-502.

Díaz, P., Guerrero, M. C., Alcorlo, P., Baltanás, A., Florín, M., \& Montes, C. (1998). Anthropogenic perturbations to the trophic structure in a permanent hypersaline shallow lake: La Salada de Chiprana (north-eastern Spain). International Journal of Salt Lake Research, 7, 187-210.

Dhont, J., \& Sorgeloos, P. (2002). Applications of Artemia. In T. J. Abatzopoulos, J. A. Beardmore, J. S. Clegg, \& P. Sorgeloos (Eds.), Artemia: Basic and applied biology (pp. 251-277). Dordrecht: Kluwer Academia Publisher.

Dudgeon, D., Arthington, A. H., Gessner, M. O., \& Sullivan, C. A. (2006). Freshwater biodiversity: Importance, threats, status and conservation challenges. Biological Reviews, 81, 163-182.

Figuerola, J., \& Green, A. J. (2002). Dispersal of aquatic organisms by waterbirds: A review of past research and priorities for future studies. Freshwater Biology, 47, 483-494.

Frisch, D., Rodríguez-Pérez, H., \& Green, A. J. (2006). Invasion of artificial ponds in Doñana Natural Park, southwest Spain, by an exotic estuarine copepod. Marine and Freshwater Ecosystem, 16, $483-492$.

Gajardo, G., \& Beardmore, J. A. (2001). Coadaptation: lessons from the brine shrimp Artemia, 'the aquatic Drosophila' (Crustacea; Anostraca). Revista Chilena de Historia Natural, 74, 65-72.

Georgiev, B. B., Sánchez, M. I., Vasileva, G. P., Nikolov, P. N., \& Green, A. J. (2007). Cestode parasitism in invasive and native brine shrimps (Artemia spp.) as a possible factor promoting the rapid invasion of A. franciscana in the Mediterranean region. Parasitology Research, 101, 1647-1655.

Gherardi, F. (2007). In G. Francesca (Ed.), Biological invaders in inland waters: Profiles, distribution, and threats (p. 733). The Netherlands: Springer.

Gisbert, E., \& López, M. A. (2007). First record of a population of the exotic mummichog Fundulus heteroclitus (L., 1766) in the Mediterranean Sea basin (Ebro River delta). Journal of Fish Biology, 71, 1220-1224. 
Gómez, A., Adcock, G. J., Lunt, D. H., \& Carvalho, G. R. (2002). The interplay between colonization history and gene flow in passively dispersing zooplankton: microsatellite analysis of rotifer resting egg banks. Journal of Evolutionary Biology, 15, 158-171.

Gómez, A., Carvalho, G. R., \& Lunt, D. H. (2000). Phylogeography and regional endemism of a passively dispersing zooplankter: mitochondrial DNA variation in rotifer resting egg banks. Proceeding of the Royal Society of London B, 267, 2189-2197.

Green, A. J., \& Figuerola, J. (2005). Recent advances in the study of long-distance dispersal of aquatic invertebrates via birds. Diversity and Distributions, 11, 149-156.

Green, A. J., Jenkins, K. M., Bell, D., Morris, P. J., \& Kingsford, R. T. (2008). The potential role of waterbirds in dispersing invertebrates and plants in arid Australia. Freshwater Biology, 53, 380-392.

Green, A. J., Sánchez, M. I., Amat, F., Figuerola, J., Hontoria, F., Ruiz, O., et al. (2005). Dispersal of invasive and native brine shrimps Artemia (Anostraca) via waterbirds. Limnology and Oceanography, 50, 737-742.

Grumbine, R. E. (1994). What is Ecosystem Management? Conservation Biology, 8(1), 27-38.

Haag, C. R., \& Ebert, D. (2004). A new hypothesis to explain geographic parthenogenesis. Annales Zoologici Fennici, 41, 539-544.

Hairston, N. G. (1996). Zooplankton egg banks as biotic reservoirs in changing environments. Limnology and Oceanography, 41, 1087-1092.

Hebert, P. D. N. (1998). Variable enviroments and evolutionary diversificationi in Inland Waters. In G. R. Carvalho (Ed.), Advances in Molecular Ecology (pp. 267-290). IOS Press.

Hebert, P. D. N., \& Cristescu, M. (2002). Genetic perspective on invasions: The case of the Cladocera. Canadian Journal of Fisheries and Aquatic Sciences, 59, 1229-1234.

Hebert, P. D. N., Cywinska, A., Ball, S. L., \& Dewaard, J. R. (2003a). Biological identifications through DNA barcodes. Proceedings of the Royal Society B, 270, 313-321.

Hebert, P. D. N., Penton, E. H., Burns, J. M., Janzen, D. H., \& Hallwachs, W. (2004a). Ten species in one: DNA barcoding reveals cryptic species in the neotropical skipper butterfly Astraptes fulgerator. Proceedings of the National Academy of Sciences of the USA, 101, 41.

Hebert, P. D. N., Stoeckle, M. Y., Zemlak, T. S., \& Francis, C. M. (2004b). Identification of birds through DNA barcodes. PLOS Biology, 2, e312.

Hebert, P. D. N., Witt, J. D. S., \& Adamowicz, S. J. (2003b). Phylogeographical patterning in Daphnia ambigua: Regional divergence and intercontinental cohesion. Limnology and Oceanography, 48, 261-268.

Hou, L., Bi, X., Zou, X., He, C., Yang, L., Qu, R., et al. (2006). Molecular systematics of bisexual Artemia populations. Aquaculture Research, 37, 671-680.

Hufbauer, R. A. (2008). Biological Invasions: Paradox lost and paradise gained. Current Biology, 18(6), R246-R247.
Ishida, S., \& Taylor, D. J. (2007). Mature habitats associated with genetic divergence despite strong dispersal ability in an arthropod. BMC Evolutionary Biology, 7, 52.

Ketmaier, V., Mandatori, R., De Matthaeis, E., \& Mura, G. (2005). Molecular systematics and phylogeography in the fairy shrimp Tanymastix stagnalis based on mitochondrial DNA. Journal of Zoology, 266, 401-410.

Ketmaier, V., Zrattini, P., De Matthaeis, E., Cobolli, M., \& Mura, G. (2003). Intra- and inter-specific relationships in the six Italian species of the fairy shrimp genus Chirocephalus: Combining allozyme and mtDNA data. Journal of Zoological Systematics and Evolutionary Research, 41, 276-285.

Knowlton, N., Weigt, L. A., Solórzano, L. A., Mills, D. K., \& Bermingham, E. (1993). Divergence in proteins, mitochondrial DNA, and reproductive compatibility across the Isthmus of Panama. Science, 260, 1629-1632.

Mabuchi, K., Senou, H., \& Nishida, M. (2008). Mitochondrial DNA analysis reveals cryptic large-scale invasion of non-native genotypes of common carp (Cyprinus carpio) in Japan. Molecular Ecology, 17, 796-809.

Mayr, E. (1963). Animal species and evolution. Cambridge, MA: Belknap Press of Harvard University Press.

McMaster, K., Savage, A., Finston, T., Johnson, M. S., \& Knott, B. (2007). The recent spread of Artemia parthenogenetica in Western Australia. Hydrobiologia, 576, 39-48.

Mergeay, J., Verschuren, D., \& De Meester, L. (2005). Cryptic invasion and dispersal of an American Daphnia in East Africa. Limnology and Oceanography, 50, 1278-1283.

Meyer, C. P., \& Paulay, G. (2005). DNA barcoding: Error rates based on comprehensive sampling. PLOS Biology, 3, 2229-2238.

Mills, S., Lunt, D. H., \& Gómez, A. (2007). Global isolation by distance despite strong regional phylogeography in a small metazoan. BMC Evolutionary Biology, 7, 225.

Mitsch, W. J., \& Gosselink, J. G. (2000). The value of wetlands: Importance of scale and landscape setting. Ecological Economics, 35, 25-33.

Muñoz, J. (2007). Biodiversity conservation including uncharismatic species. Biodiversity and Conservation, 16, 2233-2235.

Muñoz, J., Gómez, A., Green, A. J., Figuerola, J., Amat, F., \& Rico, C. (2008a). Phylogeography and local endemism of the native Mediterranean brine shrimp Artemia salina (Branchiopoda: Anostraca). Molecular Ecology, 17, 3160-3177.

Muñoz, J., Green, A. J., Figuerola, J., Amat, F., \& Rico, C. (2008b). Characterization of polymorphic microsatellite markers in the brine shrimp Artemia (Branchiopoda, Anostraca). Molecular Ecology Resources.

Mura, G., Kappas, I., Baxevanis, A. D., Moscatello, S., D’Amico, Q., Lopez, G. M., et al. (2006). Morphological and molecular data reveal the presence of the invasive Artemia franciscana in Margherita di Savoia 
salterns (Italy). International Review of Hydrobiology, 91, 539-554.

Naiman, R. J. (2008). Special issue: Freshwater animal diversity assessment. Hydrobiologia, 595, 1-637.

Ortells, R., Gómez, A., \& Serra, M. (2003). Coexistence of cryptic rotifer species: Ecological and genetic characterisation of Brachionus plicatilis. Freshwater Biology, 48, 2194-2202.

Paland, S., Colbourne, J. K., \& Lynch, M. (2005). Evolutionary history of contagious asexuality in Daphnia pulex. Evolution, 59, 800-813.

Panov, V. E., Krylov, P. I., \& Riccardi, N. (2004). Role of diapause in dispersal and invasion success by aquatic invertebrates. Journal of Limnology, 63(Suppl. 1), 56-69.

Penton, E. H., Hebert, P. D. N., \& Crease, T. J. (2004). Mitochondrial DNA variation in North American populations of Daphnia obtusa: Continentalism or cryptic endemism? Molecular Ecology, 13, 97-107.

Phillips, B. L., \& Shine, R. (2006). An invasive species induces rapid adaptive change in a native predator: Cane toads and black snakes in Australia. Proceedings of the Royal Society B, 273, 1545-1550.

Picó, F. X., \& van Groenendael, J. (2007). Large-scale plant conservation in European semi-natural grassland: A population genetic perspective. Diversity and Distributions, 13, 920-926.

Ramsar Convention Bureau. (2005). Strategic framework and guidelines for the future development of the List of Wetlands of International Importance of the Convention on Wetlands (Ramsar, Iran, 1971). Available: 〈http://www.ramsar.org/key_guide_list2006_e. htm $\rangle$.

Ruebhart, D. R., Cock, I. E., \& Shaw, G. R. (2008). Invasive character of the brine shrimp Artemia franciscana Kellogg 1906 (Branchiopoda: Anostraca) and its potential impact on Australian inland hypersaline waters. Marine and Freshwater Research, 59, 587-595.

Sakai, A. K., Allendorf, F. W., Holt, J. S., Lodge, D. M., Molofsky, J., With, K. A., et al. (2001). The population biology of invasive species. Annual Review of Ecology and Systematics, 32, 305-332.

Schön, I. (2007). Did Pleistocene glaciations shape genetic patterns of European ostracods? A phylogeographic analysis of two species with asexual reproduction. Hydrobiologia, 575, 33-50.
Smith, K. F., Sax, D. F., Gaines, S. D., Guernier, V., \& Guégan, J. F. (2007). Globalization of human infectiouus disease. Ecology, 88(8), 1903-1910.

Strugnell, J. M., \& Lindgren, A. R. (2007). A barcode of life database for the Cephalopoda? Considerations and concerns. Reviews in Fish Biology and Fisheries, 17, 337-344.

Tizol-Correa, R. A. (2006). Contribución a la caracterización molecular, citogenética, morfométrica y bioquímica del camarón de salmuera Artemia de Cuba y Sur de México. Ph.D. thesis. PDF file available at: <http://iodeweb1.vliz.be/odin/bitstream/1834/1546/ 1/Tesis\%20Doctoral\%20R\%20tizol.pdf $\rangle$.

Vandel, A. (1928). La parthénogénèse géographique. Buletin de Biologie de France et Belgique, 62, 164-281.

Van Stappen, G. (2008). Artemia biodiversity in Central and Eastern Asia. Ph.D. thesis, Ghent University, Belgium. ISBN:978-90-5989-228-6.

Velasco, J., Millán, A., Hernández, J., Gutiérrez, C., Abellán, P., Sánchez, D., \& Ruiz, M. (2006). Response of biotic communities to salinity changes in a Mediterranean hypersaline stream. Saline Systems, 2, 12.

Vilá, M., \& Gimeno, I. (2006). Potential for higher invasiveness of the alien Oxalis pes-caprae on islands than on the mainland. Plant Ecology, 183, 47-53.

Walker, S. F., Bosch, J., James, T. Y., Litvintseva, A. P., Oliver-Valls, J. A., Piña, S., et al. (2008). Invasive pathogens threaten species recovery programs. Current Biology, 18(18), R853-R854.

Weider, L. J., Hobaek, A., Colbourne, J. K., Crease, T. J., Dufresne, F., \& Hebert, P. D. N. (1999a). Holarctic phylogeography of an asexual species complex I. Mitochondrial DNA variation in arctic Daphnia. Evolution, 53, 777-792.

Weider, L. J., Hobaek, A., Hebert, P. D. N., \& Crease, T. J. (1999b). Holarctic phylogeography of an asexual species complex II. Allozymic variation and clonal structure in Arctic Daphnia. Molecular Ecology, 8, 1-13.

Williamson, M. H., \& Fitter, A. (1996). The characters of successful invaders. Biological Conservation, 78, 163-170.

Zierold, T., Hanfling, B., \& Gómez, A. (2007). Recent evolution of alternative reproductive modes in the 'living fossil' Triops cancriformis. BMC Evolutionary Biology, 7, 161. 